\title{
РОЗВИТОК САМООСВІТНЬОЇ КОМПЕТЕНТНОСТІ СУЧАСНОГО ВЧИТЕЛЯ ЯК ТЕОРЕТИКО-ПРАКСІОЛОГІЧНА ПРОБЛЕМА
}

Коновал О. А., Туркот Т. І. Розвиток самоосвітньої компетентності сучасного вчителя як теоретико-праксіологічна проблема.

У статті проаналізовано результати дослідно-експериментальної роботи, проведеної 3 метою пошуку ефективних дидактичних засобів самостійної роботи студентів вищих педагогічних навчальних закладів. За результатами аналізу авторами обгрунтовано необхідність вивчення проблеми професійно-педагогічної самоосвіти на засадах компетентнісного підходу, визначені вимоги до самоосвітньої компетентності сучасного вчителя, з'ясовано причини зниження мотивації до самостійної діяльності, запропоновані заходи щодо розвитку самоосвітньої компетентності студента та вчителя-практика в сучасному освітньому середовищі.

Ключові слова: самостійна навчальна діяльність, самоосвітня діяльність, компетентність, компетентнісний підхід.

Коновал А. А., Туркот Т. И. Развитие самообразовательной компетентности современного учителя как теоретико-праксиологическая проблема.

В статье проанализированы результаты опытно-экспериментальной работы, проведенной с целью поиска эффективных дидактических средств самостоятельной работы студентов высших педагогических учебных заведений. По результатам анализа авторами обоснована необходимость изучения проблемы профессионально-педагогического самообразования на основе компетентностного подхода. Определены требования к самообразовательной компетентности современного учителя, выяснены причины снижения мотивации к самостоятельной деятельности, предложены мероприятия по развитию самообразовательной компетентности студента и учителя-практика в современной образовательной среде.

Ключевые слова: самостоятельная учебная деятельность, самообразовательная деятельность, компетентность, компетентностный подход.

Konoval O. A. Turkot T. I. The development of self-educational competence of a contemporary teacher as a theoretical and praxiological problem.

The article analyzes the results of the experimental work conducted to find effective means of self-guided students' work in higher educational institutions. According to the results of conducted analysis the authors substantiate the necessity of researching the problem of professional and pedagogical self-education on the basis of competence approach. The requirements for selfeducational competency of contemporary teachers are defined. The reasons of reduced motivation for self-educational competence are clarified. The measures concerning the development of selfeducational competence of students and practical teachers in contemporary educational environment are proposed.

Key words: self-learning activities, self-educational activity, competence, competence approach. 
Світові тенденції переходу до постіндустріального інформаційного суспільства, а також стрімкі соціально-економічні процеси, якими охоплені нині країни світової спільноти, актуалізують проблему якості освіти як головної умови прогресу людства в третьому тисячолітті. Зміни в системі освіти України трансформуються нині в нові вимоги до змісту й організації навчального процесу у вищій педагогічній школі й організації самостійної навчальної діяльності (СНД) студентів як його невід’ ємної частини.

Питання самостійності суб' єктів навчання були предметом зацікавленості мислителів ще за давніх часів, що знайшло відбиток у філософській думці Античності, представленій Аристотелем, Демокрітом, Платоном, Сократом, у повчаннях Володимира Мономаха, у працях мислителів епохи Відродження - П. Беринди, І. Вишенського, Ю. Дрогобича, М. Монтеня, Е. Роттердамського, П. Русина, Є. Славинецького, часів Просвітництва (Я. Коменський, М. Ломоносов, Й-Г. Песталоцці, Ф. Прокопович, Ж-Ж. Руссо, Г. Сковорода та ін). Так, Я. А. Коменський у своїй знаменитій «Великій дидактиці» заявляв, що «альфою i омегою школи має стати метод, за допомогою якого учителі б менше учили, а учні б більше вчилися; у школах було б менше одуріння, даремної праці, а більше б дозвілля, радощів і обгрунтованого успіху» [4, с. 243]. «Учитель німецьких учителів» А. Дістервег сформулював відому дидактичну вимогу: «Розвиток і освіта від однієї людини до іншої не можуть бути наданими або повідомленими. Усякий, хто бажає до них долучитися, повинен досягти цього власною діяльністю, власними зусиллями, власним напруженням».

У XX-XXI століттях проблема підвищення якості професійної підготовки молодого покоління і відповідно вимоги до організації самостійної пізнавальної діяльності суб'єктів навчання набувають академічного бачення, і відповідно до цього розлогого вивчення, що знайшло відображення в результатах наукових розвідок Є. Голанта, Б. Ссіпова, В. Краєвського, І. Лернера, М. Скаткіна, В. Сластьоніна, В. Буряка, О. Малихіна, О. Савченко та інших дидактів. Початок третього тисячоліття ознаменувався активізацією дослідницького інтересу до теоретико-праксіологічних проблем забезпечення якості СНД студентів вищої школи. Цей інтерес викликаний низкою обставин, а саме:

- вибухоподібне зростання інформації вимагає від фахівців вищої кваліфікації постійної самоосвіти, вміння якої повинна закладати «Альма-матер»;

- в умовах ринкової економіки конкурентоспроможними будуть тільки ті фахівці, які в реальній практиці зможуть нестандартно мислити, творчо застосувати знання в постійно змінюваних виробничих і соціальних ситуаціях;

- практично поза межами системних науково-педагогічних досліджень залишилися умови, дидактичні можливості й засоби управління самостійною роботою студентів із використанням нових дидактичних (зокрема, інформаційних) технологій;

- досить пунктирними ми вважаємо наукові дослідження в галузі методики організації самостійної роботи студентів (СРС) при вивченні природничо-математичних дисциплін $\mathrm{i}$ конкретних тем (зокрема, електродинаміки та спеціальної теорії відносності в курсі «Теоретична фізика»).

Розуміння цих обставин та критично-конструктивний аналіз результатів наукових досліджень і набутого педагогічного досвіду [8; 11; 14; 15 та ін.] спонукали творчу групу науково-педагогічних працівників Криворізького педагогічного інституту ДВНЗ «Криворізький національний університет» до роботи над проектом «Дидактичні засоби самостійної роботи студентів». Висвітлення деяких результатів дослідно-експериментальної діяльності з метою пошуку подальших перспектив удосконалення самостійної навчальної 
діяльності студентів педагогічних ВНЗ та самоосвітньої діяльності вчителів-практиків на засадах компетентнісного підходу ми визначаємо метою пропонованої статті.

Відповідно до окресленої мети схарактеризуємо оглядово наукову новизну та практичну значущість результатів, отриманих у процесі дослідно-експериментальної роботи.

- Теоретично обгрунтовано зміст теоретико-методологічних (системний, аксіологічний, синергетичний) та методико-праксіологічних (особистісно зорієнтований, особистісно-діяльнісний, компетентісний, акмеологічний, ресурсний, рефлексивний та інноваційно-дослідницький) підходів до організації самостійної роботи студентів, покладених в основу впровадження в освітньо-інформаційний простір сучасного ВНЗ науково-методичного комплексу нових дидактичних засобів СРС.

- Розроблено та обгрунтовано інноваційну «Модель організації самостійної роботи студентів вищих педагогічних навчальних закладів».

- Запропоновано систему принципів організації СРС в умовах модернізації професійної підготовки вчителів фізики (фундаменталізації, бінарності, синергетизму, системності, самостійності та активності, наступності, альтернативності, інтеграції, індивідуально-диференційованого підходу до студентів, педагогічної рефлексії). Визначено можливості адаптації цих принципів до організації СРС під час вивчення теоретичної фізики (зокрема, спеціальної теорії відносності), а також інших природничо-математичних дисциплін.

- 3 позицій особистісно зорієнтованої освіти удосконалено методику використання комп'ютерних дидактичних засобів у розробленні індивідуальних сценаріїв самостійної роботи студентів 3 урахуванням рівня їх готовності до навчально-пізнавальної діяльності та специфіки стилів цієї діяльності.

- Розроблено класифікацію комп'ютерних засобів підтримки СРС та встановлено дидактичні можливості комп'ютерних навчальних програм щодо моделювання фізичних процесів. Запропоновано систему індивідуалізованих завдань для СРС при вивченні електродинаміки та спеціальної теорії відносності з використанням програми «Компонент».

- У руслі модернізації вищої освіти України науково обгрунтовано зміст, структуру й розроблено програму елективного курсу «Шляхи і методи підвищення ефективності самостійної роботи студентів» і науково-методичний комплекс до нього.

- Визначено дидактичні вимоги та принципи конструювання навчальних посібників і підручників з фізики та методики ії навчання, орієнтованих на організацію СРС.

- Обгрунтовано необхідність подальшого вдосконалення технологій професійнопедагогічної самоосвітньої діяльності фахівців-фізиків в системі університетської та післядипломної освіти.

- Доведено як необхідність так і можливість адаптації системи дидактичних засобів самостійної роботи до вивчення спеціальної теорії відносності в ВНЗ та релятивістської механіки в загальноосвітніх навчальних закладах в умовах профільної диференціації [13].

Водночас у процесі дослідно-експериментальної роботи було звернено увагу на наявність теоретико-праксіологічних проблем забезпечення ефективності самостійної навчальної діяльності, вирішення яких, на наш погляд, наблизить рівень професійнопедагогічної підготовки майбутніх учителів до сприйняття, розуміння і реального вирішення завдань, які окреслює нова європейська освітня парадигма «навчання протягом усього життя». У зв'язку з цим ми вважаємо необхідним більш глибоке занурення у висвітлення проблеми самоосвіти вчителя на засадах компетентнісного підходу. У цьому контексті 
актуальним нам вбачається зауваження I. Хворостенко: «Незважаючи на зацікавленість науковців проблематикою самоосвітньої компетентності, роботу щодо дослідження рівнів сформованості та розвитку самоосвітньої компетентності тільки розпочато» [14, с. 139]. Ураховуючи розлогі дискусії навколо понять «компетентність» $[2 ; 3 ; 5 ; 7 ; 11]$, «самоосвітня компетентність» $[14 ; 15]$, звернемось до більш детального з'ясування їх сутності.

Згідно 3 визначенням Міжнародного департаменту Стандартів для навчання, досягнення та освіти (International Board of Standards for Training, Performance and Instruction (IBSPI)), поняття «компетентність» визначається як спроможність кваліфіковано здійснювати діяльність, виконувати завдання або роботу. При цьому дане поняття містить набір знань, навичок та ставлень, що надають змогу особистості ефективно здійснювати діяльність або виконувати певні функції, що підлягають досягненню певних стандартів у галузі професії або виду діяльності [12, с. 30]. Л. Лісіна аналізує чотири загальні концепції компетентності, запропоновані американським дослідником Е. Шортом. Згідно з першою концепцією, термін «компетентність» тлумачиться як поведінка або дія, тому iï розуміння пов'язується 3 набуванням людиною вмінь і навичок задля певної діяльності, що не має творчого характеру. У другій концепції пропонується розглядати компетентність як володіння знаннями, вміннями та навичками. Людина в кожній своїй професійній дії свідомо робить вибір, досконало володіючи своєю діяльністю; користується різноманітністю своїх знань і навичок, щоб визначити, яку саме діяльність здійснювати і як вона має відбуватися. За третьою концепцією компетентність науковець пропонує розглядати за ступенем або рівнем здібностей, що офіційно вважається достатнім. За таким тлумаченням оцінка компетентності повинна даватися відповідно до певних державних стандартів чи критеріїв якості. Вона має відповідати рівню, прийнятому в професійній галузі або у сфері діяльності. За четвертою концепцією компетентність визначається як властивість або спосіб буття людини. Отже, на думку Е. Шорта, для здійснення аналізу сутності тієї або іншої компетентності необхідним $є$ визначення концепції, в межах якої цей аналіз і буде відбуватися [6, с. 15].

Ю. Громико [1, с. 7] пропонує трактувати поняття «компетентність» 3 двох різних позицій. Перша позиція - під компетентністю розуміють розумово-діяльнісну здатність, для формування якої необхідна рефлексивна логіко-філософська й особистісно-гуманітарна культура. 3 цим трактуванням автор пов'язує роботи Г. Щедровицького і В. Давидова, оскільки ними була створена персонологічна практика подібної освіти. У другому трактуванні під терміном «компетентність» розуміють соціальне адаптивне вміння, яке потім закріплюється спеціально створеними тестами. Реалізація другого напряму, на думку вчених, вимагає метапредметності й міждисциплінарності, передбачає кардинальну зміну форм розробки змісту, формування нових цінностей освіти. Таке трактування компетентності виявляється у вигляді рольових, а не позиційних принципів організації особистості: умінні знаходити інформацію, а не породжувати знання; в умінні пристосовуватися до ринку праці, а не проектувати нові інституціональні форми. Такий погляд на проблему компетентності, на нашу думку, виглядає дискусійним, адже в певній мірі обмежує право особистості «породжувати знання». При з'ясуванні сутності компетентнісної ідеї в навчанні нам більш близькою є позиція, відповідно якої «Компетентність передбачає обізнаність індивіда 3 процесом навчання та усвідомлення власних навчально-пізнавальних потреб та можливостей. Вона передбачає набуття, переробку, асиміляцію нових знань та навичок. Уміння вчитися враховує попередні знання та навички в різних контекстах - у побуті, на роботі, у навчанні та професійній підготовці. Мотивація та впевненість $€$ визначальними характеристиками компетентної особистості» [7, с. 30]. 
Згідно з переліком ключових компетентностей, визначеного українськими педагогами (за матеріалами дискусій, організованих у межах проекту ПРООН «Освітня політика та освіта «Рівний рівному», 2004 р.), компетентність «уміння вчитися» «дає змогу особистості, яка звикла вчитися самостійно, не губитися в новій пізнавальній і життєвій ситуації, не зупинятися, якщо немає готових рішень, не чекати підказки, а самій шукати джерело інформації, шляхи розв'язання, адже вміння вчитися змінює іiї стиль мислення і життя» [5, c. 86].

Важливо зважити на слушну думку В. Олійника, який переконаний: «щоб сформувати суспільство, яке навчається, потрібно створити умови для вчителя, який навчається, володіє найсучаснішими методологічними, теоретичними і методичними знаннями європейського рівня та напрацьовує суспільні міжнародні орієнтири. Учитель повинен учитися протягом життя» [9, с. 11].

О. Чеботарьова обгрунтовує необхідність використання терміну «самоосвітня компетентність» і пропонує розглядати ï сутність як інтегративну властивість особистості, що забезпечується пї емоційно-ціннісним ставленням до саморозвитку й самоосвітньої діяльності, системою знань про планування й реалізацію самоосвітньої діяльності, про способи самовиховання; суб'єктно-особистісним досвідом продуктивного розв'язання проблем розвитку, розробки й реалізації моделей підготовки студентів до самоосвітньої діяльності; готовністю до безперервного саморозвитку якостей професіонала, самовдосконалення, самоосвіти в галузі майбутньої професії [15].

Аналізуючи сутність самоосвітньої компетентності, слушним уважаємо врахувати запропоновану В. Іванютіною її структуру, що має такі елементи:

- здатність до самоосвіти, організації власних прийомів самонавчання;

- відповідальність за рівень власної самоосвітньої діяльності;

- гнучкість застосування знань, умінь і навичок в умовах швидких змін;

- постійний самоаналіз, контроль своєї діяльності [3].

Теоретичний аналіз різних наукових підходів до розуміння сутності самоосвітньої компетентності надав змогу дійти висновку, що самоосвітня компетентність $є$ інтегрованим багатокомпонентним особистісним утворенням, яке відображає єдність теоретичної й практичної готовності та здатності особистості до ефективного планування, здійснення самоосвітньої діяльності, ii самоаналізу та самоконтролю з використанням новітніх форм навчально-інформаційних ресурсів з метою неперервного самовдосконалення особистісних, соціальних та професійних функцій. Водночас, розвиток самоосвітньої компетентності ми розуміємо як результат і як процес розвитку людини під впливом особистісної мотивації та зовнішніх умов, що продовжується протягом життя.

У праксіологічній площині дослідницький інтерес викликають причини зниження інтересу та мотивації студентів до самостійної навчальної діяльності, що об'єктивно впливає на рівень самоосвітньої компетентності сучасного вчителя. Це явище ми спостерігаємо в практиці навчання студентів фізико-математичного факультету Криворізького педагогічного інституту та в системі післядипломної педагогічної освіти (КВНЗ «Херсонська академія неперервної освіти»).

Результати своїх спостережень ми проаналізували, узагальнили та запропонували заходи щодо стимулювання розвитку самоосвітньої компетентності вчителя в умовах сучасності, що знайшло відображення у таблиці 1.

Отже, не претендуючи на єдиний варіант вирішення проблеми забезпечення 
самоосвітньої компетентності сучасного вчителя, пропонуємо деякі кроки, які, на наш погляд, можуть позитивно вплинути на цей процес:

- на засадах класичних принципів системності та наступності має сенс створити так звану таксономію цілей, завдань і засобів самостійної навчальної діяльності учнів ЗНЗ та студентів ВНЗ, самоосвітньої діяльності учителів у системі післядипломної освіти;

- відійти від декларації щодо необхідності особистісно зорієнтованого навчання до реалізації його принципів на всіх етапах освітньої траєкторії особистості (дошкілля $\rightarrow$ школа $\rightarrow$ ВНЗ $\rightarrow$ післядипломна освіта);

- забезпечити навчання педагогічному прогнозуванню й педагогічній рефлексії студентів педагогічних вишів й удосконалення цих умінь в системі післядипломної освіти..

На завершення дозволимо собі процитувати відомих дослідників у галузі дидактики вищої школи В. Попкова та А. Коржуєва, з провідною ідеєю яких щодо забезпечення самоосвітньої компетентності вчителя ми повністю солідаризуємося: «Виходом із цього стану є постійна самоосвітня діяльність, розвиток у собі кожним педагогом-дослідником непереборного бажання до читання, особливо класичної, філософської, педагогічної та психологічної літератури, долаючи шаблонність і зашкарублість щоденної свідомості, розвиваючи в собі педагогічне мислення та здібності рахуватися 3 доказами розуму» [10, c. 51]. 
Реальний стан та заходи щодо розвитку самоосвітньої компетентності вчителя

\section{Професійні вимоги до самоосвітньої компетентності вчителя}

\section{Причини зниження мотивації до забезпечення самоосвітньої компетентності}

Учитель завантажений проведенням уроків

\section{Заходи щодо розвитку самоосвітньої компетентності}

Розвантажити вчителя від

1. Систематично займатися та підготовкою до них (зазвичай кількість «паперотворчості», зменшити кількість заходів самоосвітою; заздалегідь планувати щотижневих підготовок складає 18-24), а також колективного характеру, акцентувати увагу самоосвітню діяльність, визначаючи проведенням заходів виховного та організаційного вчителя на індивідуальній роботі 3 учнями, для цього місце i час, оптимально характеру (підготовка учнів до різноманітних вивільнити його час на самоосвітню діяльність. поєднуючи працю і відпочинок. конкурсів, змагань, написання звітів та ін.).

2. Забезпечувати науковий У загальноосвітніх навчальних закладах Стимулювати вчителя до вивчення підхід до педагогічної діяльності на мало звертають уваги на теоретичну підготовку теоретичних джерел, відмови від сліпого засадах опрацювання та аналізу вчителя. Увага акцентується на упровадженні копіювання дидактичних технологій, психолого-педагогічної та науково- інноваційних технологій, без їх достатнього формування пізнавального інтересу до методичної літератури. теоретичного обгрунтування та прогнозування теоретичного осмислення і творчого результатів як дидактичного, так і використання технологій 3 урахуванням здоров'язбережувального характеру. особливостей класу, власного педагогічного потенціалу, зважаючи на педагогічну аксіому, сформульовану В.О. Сухомлинським: «Педагогічна теорія повинна бути сприятливим компасом, який указує куди і як вести дитину, світлом, яке осяює практику».

3. Уміти працювати з Учителі, особливо в сільській місцевості, Посилювати вплив дистанційної освіти. джерелами інформації (добирати віддалені від наукових та науково-методичних потрібну літературу, орієнтуватися в центрів, бібліотек, мають обмежений доступ до каталогах, тематичних словниках, інформаційних ресурсів. Методичні кабінети в 


\section{Професійні вимоги до \\ самоосвітньої}

компетентності вчителя

\section{Причини зниження мотивації до забезпечення самоосвітньої компетентності}

\section{Заходи щодо розвитку самоосвітньої компетентност}

довідковій літературі, періодиці, районних, обласних центрах іноді перебирають на Інтернет-ресурсах). себе контролюючі функції. Методична література дуже часто має рецептурний характер i не спонукає учителів до критично-конструктивного аналізу наданих рекомендацій.

\section{4. Уміти моделювати Учителі слабо володіють основами}

Упроваджувати в навчальний процес педагогічну діяльність на засадах психолого-педагогічної діагностики, моделюють вищих педагогічних навчальних закладів та в інтеграції психологічних, педагогічних педагогічну діяльність на інтуїтивному рівні. систему післядипломної освіти інтегровані та методичних знань.

5. Уміти об'єктивно оцінювати

При вивченні педагогіки, психології, курси психопедагогіки, психодидактики (зокрема, психодидактики фізики, лінгводидактики та ін.).

процес та результати педагогічної методик викладання недостатньо аналітико-прогностичної та рефлексивної діяльності, виявляти причини успіхів використовуються методи навчання студентів в діяльності майбутнього педагога у вищих чи помилок, визначати шляхи аналітико-прогностичній та рефлексивній навчальних закладах; пропонувати об'єктивні усунення невдач. діяльності. В освітній площині оцінка діяльності показники якості педагогічної діяльності. вчителя часто здійснюється суб'єктивно.

6. Умови діяльності вчителя У суспільстві часто має місце: Підвищувати значущість педагогічної повинні бути організаційно та необгрунтована критика педагогічної діяльності, праці, повагу до професійно компетентного психологічно сприятливими, загроза втрати роботи через скорочення штатів, вчителя, забезпечувати комфортні умови адміністративний тиск на педагога закриття шкіл, зменшення навантаження тощо. педагогічної діяльності.

відсутній. 


\section{Література}

1. Громыко Ю. В. Образование перестает быть гуманитарной технологией / Ю. В. Громыко // Вести Международного Соломонова ун-та. - 2000. - № 4. - С. 4-10. 2. Дзега В. Організаційно-методичне забезпечення вдосконалення професійної компетентності педагогічних працівників сільської школи на андрагогічних засадах / Володимир Дзега // Нова педагогічна думка : [науково-методичний журнал]. - 2013. - № 3 (75). - С. 36-40. 3. Иванютина В. Н. Формирование ключевых компетентностей учеников на уроках математики [Электронный ресурс]/ В. Н. Иванютина. - Режим доступа : http://festival.1september.ru/articles/416315/. 4. Коменский Я. А. Избранные педагогические сочинения [текст] : в 2 т. / Я.А. Коменский; под ред. А. И. Пискунова. - Москва : Педагогика, 1982. - Т. 1. - 693 с. 5. Компетентнісний підхід у сучасній освіті : світовий досвід та українські перспективи / за заг. ред. О. В. Овчарук. - Київ : К.І.С., 2004. - 112 с. 6. Лісіна Л. О. Формування професійної компетентності вчителя : [навч. метод. посібник] / Л. О. Лісіна, О. О. Барліт. - Запоріжжя : Лана-Друк, 2006. - 212 с. 7. Локшина О. I. Становлення компетентнісної ідеї в європейські освіті [текст] / О. І. Локшина / Реалізація європейського досвіду компетентнісного підходу у вищій школі України: Матеріали методолог. семінару. - Київ : Педагогічна думка, 2009. - 360 с. 8. Малихін О. Зміст і сутність самостійної навчальної діяльності студентів : історія і сучасність / О. Малихін // Українська мова і література в школах України. - 2014. - № 11. - С. 24 -27. 9. Олійник В. В. Стан та перспективи модернізації системи фахового зростання педагогічних працівників України / В. В. Олійник // Освіта на Луганщині. - 2002. - № 1 (16). - С. 11-14. 10. Попков В. А. Дидактика высшей школы : [учеб. пособие для студ. высш. учеб. заведений] / В. А. Попков, А. В. Коржуєв. - [2-е изд., испр. и доп.]. - Москва : Издательский центр «Академия», 2004. 192 с. 11. Савченко О. Я. Уміння вчитися - ключова компетентність молодшого школяра : [посібник] / О.Я.Савченко. - Київ : Педагогічна думка, 2014. - 176 с. 12. Стратегія реформування освіти в Україні : рекомендації освітньої політики. - Київ : К.І.С., 2003. 296 с. 13. Теорія і практика організації самостійної роботи студентів вищих навчальних закладів : [монографія]/ колектив авторів ; за ред. проф. О. А. Коновала. - Кривий Ріг : Книжкове видавництво Кирєєвського, 2012. - 380 с. 14. Хворостенко I. Розвиток самоосвітньої компетентності як психолого-педагогічна проблема / Ірина Хворостенко // Нова педагогічна думка : [науково-методичний журнал]. - 2013. - № 3 (75). - С. 137-140. 15. Чеботарева Е. С. Информационные технологии в развитии самообразовательной компетентности студентов [Электронный ресурс]/ Е. С. Чеботарева. - Режим доступа : http://ito.edu.ru/2008/kursk.html/

Наталія Самовілова

\section{ДОСВІД ЗАКОРДОННИХ УНІВЕРСИТЕТІВ У ПІДТРИМЦІ ВИРОБНИЧОЇ ПРАКТИКИ СТУДЕНТІВ}

Самовілова Н. О. Досвід закордонних університетів у підтримці виробничої практики студентів.

У статті аналізується закордонний досвід організації виробничої практики студентів та випускників, з'ясовуються іiі сутність та форми: стажування, віртуальне стажування, сендвіч-курси. Розглядається зміст підтримки майбутніх фахівців центрами розвитку кар'єри шляхом аналізу сайтів провідних університетів США. 